\title{
The Use of Accounting Information in Financing Decision: The Context of Bangladeshi Private Commercial Banks
}

\author{
Sumi Saha ${ }^{1}$, Subhash Chandra Sil ${ }^{2}$, Md. Sayaduzzaman ${ }^{3}$ \\ ${ }^{1}$ Assistant Professor, Department of Accounting and Information Systems (AIS), University of Rajshahi, Rajshahi-6205, BANGLADESH \\ 2,3Professor, Department of Accounting and Information Systems (AIS), University of Rajshahi, Rajshahi-6205, BANGLADESH
}

https://doi.org/10.18034/abr.v11i1.514

\begin{abstract}
Accounting information is essential to elucidate the financial scenario of any organization. The use of accounting information enhances the decision-making process that has a good role in managerial efficiency. This research study has attempted to know the use of accounting information contained in the annual reports in making a financing decision. Five components of financing decision like selecting the best source of financing, assessing the cash flows, preparing the budget and profit planning, valuation of bond and share as well as financial statement analysis have been considered for the purpose of the study and collected opinions from the selected respondents amounts to one hundred fifty with the use of structured questionnaire and the outcomes of this survey report that the most of the respondents strongly agreed that the accounting information has been used in making a financing decision. The study also reveals that there is a significant relationship among the opinions of the respondents regarding using accounting information in making decisions about the different components of financing decisions.
\end{abstract}

Key words: Financial statements, accounting information, financing decisions, conventional private commercial banks

\section{INTRODUCTION}

Banking industry plays a significant role in maintaining the stable capital market and it has a good significant impact on the entire economy of any country. The banking industry is one of the most important components of financial systems that mobilize the resources for economic development. A sound banking system is fundamental requirement for the economic development because banks accumulate the savings of customers and channelize them through the productive sector. So, the effective banking system is essential for the interested parties as well as the success of any economy. The structure of financial sector of Bangladesh has been developed by the state-owned commercial banks as well as specialized banks; conventional private commercial banks, Islamic Sariah based private commercial banks, foreign commercial banks and non-bank financial institutions and banks play the important role in the financial systems of Bangladesh. The commercial banks, especially of the private sector are one of the most service providing organization and the momentous contributor to economic development. For creating a significant position in the economic development the information about banking industry is most important to the different stakeholders for making sound decisions and the proper use of accounting information is to help users in making efficient and effective decisions which is necessary to ensure the success and survival of any organization.

Accounting information is needed most by the firm and it is particularly used in meeting the different needs. Accounting information is the output of accounting information system and the smart accounting information system assist in creating good decision by providing accurate information timely (Das and Das, 2008). Accounting information provided through the different financial statements is one of the most effective used tools in decision making process. Financial statements convey the information about the operating result and financial position of any business. They are the most effective source of accounting information that help the different decision makers make good decision as per their requirements and the interested users always show intention to get quality accounting information. Currently there is an increasing tendency among the different interested stakeholders of using accounting information in making logical decision in the respective field because 
the accounting information is indispensable way to gather proper knowledge about the financial scenario of any organization. In this research study an attempt has been made to scrutinize the perceptions of the respondents regarding the use of accounting information in making financing decision in banking industry of Bangladesh.

\section{Objectives of the Study}

The central aim of this study is to evaluate the perceptions of the designated respondents regarding the use of accounting information in the different components of financing decision made by the interested stakeholders and the specific objectives are:

- To analyze the frequency of using accounting information in making financing decisions provided by the selected respondents.

- To evaluate the variation in different respondent perceptions about the use of accounting information in making financing decision by the interested stakeholders.

\section{Hypothesis of the Study}

Taking into consideration the related literatures this research study has formulated and tested the following null hypotheses:

Ho1: There is no significant variation of perceptions among the respondents regarding the use of accounting information in making decisions about the different components of financing decisions.

\section{REVIEW OF LITERATURES}

Nnenna (2012) revealed that the using accounting information makes rich the decision making process and there is a strong relationship between the use of accounting information and managerial efficiency in organizations. Tunji (2012) stated that accounting information has significant role as well as influence on management decisions. Socea (2012) expressed that the accounting information is important components to the manager due to determine the meaning and significance of all the operations related with past and present situation of the business concern that is helped to be prepared for future activities and decisions. Srivastava and Lognathan (2016) reported that the adequate as well as proper use of accounting information assists to the management in making healthy decision also reported that there is a significant impact of using accounting information as an aid to management decision making process. Ullah, Khonadakar and Fahim (2014) stated that the $44.44 \%$ of respondents have used accounting information in making strategic decision in case of manufacturing industries of Bangladesh also stated that there is significant relationship between accounting information and strategic decisions and the entire selected areas of strategic decision in significantly depend on accounting information.

\section{Methodology OF THE StUdy}

The sample of the study has been selected by taking ten conventional private commercial banks enlisted in the Dhaka Stock Exchange functioning in Bangladesh such as Pubali Bank Limited, Uttara Bank Limited, National Bank Limited, AB Bank Limited, IFIC Bank Limited, Dutch Bangle Bank Limited, National Credit and Commerce Bank Limited, Preminer Bank Limited, One Bank Limited and Eastern Bank Limited and the selection of the banks is based on the facility of data collection by using the purposive sampling technique to meet the research objectives. This study has used basically primary data which have collected through sending the structured questionnaire to the designated respondents with the use of direct interview method which consists of fifteen bank executives of each sample banks and this set of questionnaire has been developed taking into consideration the relevant literatures as well as expert opinions using a five point of Likert model such as strongly agree $=5$, moderately agree $=4$, slightly agree $=3$, neutral $=2$ and disagree $=1$. The questionnaire has been divided into two parts, one part is related with demographical information of the respondents and another part is concerned with the use of accounting information in making decisions about the different components of financing decision. After collecting the required data this study has utilized the different parts of descriptive statistics like mean, standard deviation, variance and utilized ANOVA technique as well as t-test through formulating the different null hypotheses by using SPSS software to reveal the study findings.

\section{ANALYSIS AND FINDINGS}

Component One: The perceptions of the respondents about the using of accounting information in selecting the best source of financing

Table 1: Table showing the results of frequency and percentage of respondents' opinions

\begin{tabular}{|c|c|c|c|c|}
\hline \multirow[b]{2}{*}{ Opinions } & \multicolumn{3}{|c|}{ Banks Executives } & \multirow{2}{*}{$\begin{array}{c}\text { Total } \\
(\mathrm{F} \text { and } \%)\end{array}$} \\
\hline & $\begin{array}{c}\text { BE_1 } \\
(\mathrm{F} \text { and } \%)\end{array}$ & $\begin{array}{c}\text { BE_2 } \\
(\mathrm{F} \text { and } \%)\end{array}$ & $\begin{array}{c}\text { BE_3 } \\
(\mathrm{F} \text { and } \%)\end{array}$ & \\
\hline Strongly Agreed & $40(80 \%)$ & $32(64 \%)$ & $30(60 \%)$ & $102(68 \%)$ \\
\hline $\begin{array}{c}\text { Moderately } \\
\text { Agreed }\end{array}$ & $7(14 \%)$ & $17(34 \%)$ & $16(32 \%)$ & $40(26.67 \%)$ \\
\hline Slightly Agreed & $3(6 \%)$ & $1(2 \%)$ & $2(4 \%)$ & $6(4 \%)$ \\
\hline Neutral & $0(0 \%)$ & $0(0 \%)$ & $2(4 \%)$ & $2(1.33 \%)$ \\
\hline Disagreed & $0(0 \%)$ & $0(0 \%)$ & $0(0 \%)$ & $0(0 \%)$ \\
\hline Total & $50(100 \%)$ & $50(100 \%)$ & $50(100 \%)$ & $150(100 \%)$ \\
\hline
\end{tabular}

Source: Analysis of Opinion Survey Statement

It has been obtained from the aforesaid outcomes that $68.00 \%$ of the respondents strongly agreed that accounting 
information has been used in making decision about the selecting best source of financing and none of the respondents disagreed with this point. Moreover, it has also been found that $26.67 \%$ of the respondents moderately agreed as well as $4.00 \%$ of the respondents slightly agreed but $1.33 \%$ of the respondents were neutral in this regard. Taking highest percentage into consideration it can be concluded that the interested stakeholders have been employed accounting information in case of selecting best source of financing as a part of financing decision.

Component Two: The perceptions of the respondents about the using accounting information in assessing cash flows

Table 2: Table showing the results of frequency and percentage of respondent opinions

\begin{tabular}{|c|c|c|c|c|}
\hline \multirow{2}{*}{ Opinions } & \multicolumn{3}{|c|}{ Banks Executives } & \multirow{2}{*}{$\begin{array}{c}\text { Total } \\
\text { (F and \%) }\end{array}$} \\
\cline { 2 - 4 } & $\begin{array}{c}\text { BE_1 } \\
(\mathrm{F} \text { and \%) }\end{array}$ & $\begin{array}{c}\text { BE_2 } \\
\text { (F and \%) }\end{array}$ & $\begin{array}{c}\text { BE_3 } \\
\text { (F and \%) }\end{array}$ & \\
\hline Strongly Agreed & $31(62 \%)$ & $34(68 \%)$ & $30(60 \%)$ & $95(63.33 \%)$ \\
\hline $\begin{array}{c}\text { Moderately } \\
\text { Agreed }\end{array}$ & $14(28 \%)$ & $13(26 \%)$ & $16(32 \%)$ & $43(28.67 \%)$ \\
\hline Slightly Agreed & $5(10 \%)$ & $3(6 \%)$ & $4(8 \%)$ & $12(8 \%)$ \\
\hline Neutral & $0(0 \%)$ & $0(0 \%)$ & $0(0 \%)$ & $0(0 \%)$ \\
\hline Disagreed & $0(0 \%)$ & $0(0 \%)$ & $0(0 \%)$ & $0(0 \%)$ \\
\hline Total & $50(100 \%)$ & $50(100 \%)$ & $50(100 \%)$ & $150(100 \%)$ \\
\hline
\end{tabular}

Source: Analysis of Opinion Survey Statement

The results say that $63.33 \%$ of the respondents strongly agreed and nobody disagreed that accounting information has been used to assess cash flows of any business concern. In addition $28.67 \%$ of the respondents moderately agreed and $8.00 \%$ of the respondents slightly agreed in this regard. By using the highest frequency and percentage of respondent opinions it is clear that with the use of accounting information the decision making process about the assessing cash flows has been conducted by the users.

Component Three: The perceptions of the respondents about the using accounting information in preparing budget and profit planning.

Table 3: Table showing the results of frequency and percentage of respondent opinions

\begin{tabular}{|c|c|c|c|c|}
\hline \multirow{2}{*}{ Opinions } & \multicolumn{3}{|c|}{ Banks Executives } & \multirow{2}{*}{$\begin{array}{c}\text { Total } \\
\text { (F and \%) }\end{array}$} \\
\cline { 2 - 4 } & $\begin{array}{c}\text { BE_1 } \\
\text { F and \%) }\end{array}$ & $\begin{array}{c}\text { BE_2 } \\
\text { (F and \%) }\end{array}$ & $\begin{array}{c}\text { BE_3 } \\
\text { F and \%) }\end{array}$ & \\
\hline Strongly Agreed & $27(54 \%)$ & $33(66 \%)$ & $25(50 \%)$ & $85(56.67 \%)$ \\
\hline $\begin{array}{c}\text { Moderately } \\
\text { Agreed }\end{array}$ & $15(30 \%)$ & $14(28 \%)$ & $20(40 \%)$ & $49(32.67 \%)$ \\
\hline Slightly Agreed & $8(16 \%)$ & $3(6 \%)$ & $4(4 \%)$ & $15(10 \%)$ \\
\hline Neutral & $0(0 \%)$ & $0(0 \%)$ & $1(2 \%)$ & $1(0.66 \%)$ \\
\hline Disagreed & $0(0 \%)$ & $0(0 \%)$ & $0(0 \%)$ & $0(0 \%)$ \\
\hline Total & $50(100 \%)$ & $50(100 \%)$ & $50(100 \%)$ & $150(100 \%)$ \\
\hline
\end{tabular}

Source: Analysis of Opinion Survey Statement
With the use of previous evidence it is found that $56.67 \%$ of the respondents strongly agreed and no one disagreed that the interested users have used accounting information in preparing budget and profit planning. Again $32.67 \%$ of the respondents moderately agreed and $10.00 \%$ of the respondents slightly agreed but $0.66 \%$ of the respondents did not consider giving any opinions about this matter. Based on the previous evidence it is logical to say that the stakeholders have used accounting information during the preparation of budget and profit planning.

Component Four: The perceptions of the respondents about the using accounting information in valuation of bond and share.

Table 4: Table showing the results of frequency and percentage of respondents' opinions

\begin{tabular}{|c|c|c|c|c|}
\hline \multirow[b]{2}{*}{ Opinions } & \multicolumn{3}{|c|}{ Banks Executives } & \multirow{2}{*}{$\begin{array}{c}\text { Total } \\
(\mathrm{F} \text { and } \%)\end{array}$} \\
\hline & $\begin{array}{c}\text { BE_1 } \\
(\mathrm{F} \text { and } \%)\end{array}$ & $\begin{array}{c}\text { BE_2 } \\
(\mathrm{F} \text { and } \%)\end{array}$ & \begin{tabular}{|c|} 
BE_3 \\
$(\mathrm{F}$ and $\%)$
\end{tabular} & \\
\hline Strongly Agreed & $27(54 \%)$ & $27(54 \%)$ & $26(52 \%)$ & $80(53.33 \%)$ \\
\hline $\begin{array}{c}\text { Moderately } \\
\text { Agreed }\end{array}$ & $13(26 \%)$ & $19(38 \%)$ & $19(38 \%)$ & $51(34 \%)$ \\
\hline Slightly Agreed & $7(14 \%)$ & $4(8 \%)$ & $4(8 \%)$ & $15(10 \%)$ \\
\hline Neutral & $3(6 \%)$ & $0(0 \%)$ & $1(2 \%)$ & $4(2.67 \%)$ \\
\hline Disagreed & $0(0 \%)$ & $0(0 \%)$ & $0(0 \%)$ & $0(0 \%)$ \\
\hline Total & $50(100 \%)$ & $50(100 \%)$ & $50(100 \%)$ & $150(100 \%)$ \\
\hline
\end{tabular}

Source: Analysis of Opinion Survey Statement

The above discussion reports that $53.33 \%$ of the respondents strongly agreed and nobody disagreed that by using accounting information the users have taken decision about the valuation of bond and share. Besides, $34.00 \%$ of the respondents moderately agreed and $10.00 \%$ of the respondents slightly agreed but $2.67 \%$ of the respondents were neutral on this point. Referring to the aforesaid evidence it is apparent that most of the respondents show the homogeneity regarding the using of accounting information in valuation of bond and share.

Component Five: The perceptions of the respondents about the using accounting information in financial statement analysis.

Table 5: Table showing the results of frequency and percentage of respondents' opinions

\begin{tabular}{|c|c|c|c|c|}
\hline \multirow[b]{2}{*}{ Opinions } & \multicolumn{3}{|c|}{ Banks Executives } & \multirow[b]{2}{*}{$\begin{array}{c}\text { Total } \\
(\mathrm{F} \text { and } \%)\end{array}$} \\
\hline & $\begin{array}{c}\text { BE_1 } \\
(\mathrm{F} \text { and \%) }\end{array}$ & $\begin{array}{c}\text { BE_2 } \\
(\mathrm{F} \text { and \%) }\end{array}$ & $\begin{array}{c}\text { BE_3 } \\
(\mathrm{F} \text { and \%) }\end{array}$ & \\
\hline Strongly Agreed & $30(60 \%)$ & $32(64 \%)$ & $28(56 \%)$ & $90(60 \%)$ \\
\hline $\begin{array}{c}\text { Moderately } \\
\text { Agreed }\end{array}$ & $10(20 \%)$ & $16(32 \%)$ & $16(32 \%)$ & $42(28 \%)$ \\
\hline Slightly Agreed & $7(14 \%)$ & $2(4 \%)$ & $5(10 \%)$ & $14(9.33 \%)$ \\
\hline Neutral & $3(6 \%)$ & $0(0 \%)$ & $1(2 \%)$ & $4(2.67 \%)$ \\
\hline Disagreed & $0(0 \%)$ & $0(0 \%)$ & $0(0 \%)$ & $0(0 \%)$ \\
\hline Total & $50(100 \%)$ & $50(100 \%)$ & $50(100 \%)$ & $150(100 \%)$ \\
\hline
\end{tabular}

Source: Analysis of Opinion Survey Statement 
Based on the previous discussion it is evident that $60.00 \%$ of the respondents strongly agreed that accounting information has been used by the related party in financial statement analysis and none disagreed on this point. Moreover the discussion also presents that $28.00 \%$ of the respondents moderately agreed and $8.00 \%$ of the respondents slightly agreed but $2.67 \%$ of the respondents were neutral on this point. By understanding the aforesaid results it is apparent that the interested users have used accounting information in financial statement analysis.

\section{Analysis the Results of ANOVA Technique}

With a view to investigating whether there is any significant variation of perceptions among the respondents regarding the use of accounting information in making decision about the different components of financing decisions such as selecting the best source of financing, assessing cash flows, preparing budget and profit planning, valuation of bond and share as well as financial statement analysis, this study has formulated a null hypothesis which is Ho1: There is no significant variation of perceptions among the respondents regarding the use of accounting information in making decisions about the different components of financing decisions and results in this regard are given below.

Table 6: Table showing the results of ANOVA test

\begin{tabular}{|c|c|c|c|c|c|}
\hline \multicolumn{6}{|c|}{ Component One: Selecting the Best Source of Financing } \\
\hline & Sum of Squares & $\mathrm{df}$ & Mean Square & $\mathrm{F}$ & Sig. \\
\hline Between Groups & 1.693 & 2 & 0.847 & 2.150 & 0.120 \\
\hline Within Groups & 57.880 & 147 & 0.394 & & \\
\hline Total & 59.573 & 149 & & & \\
\hline \multicolumn{6}{|c|}{ Component Two: Assessing Cash Flows } \\
\hline & Sum of Squares & $\mathrm{df}$ & Mean Square & F & Sig. \\
\hline Between Groups & 0.333 & 2 & 0.167 & 0.403 & 0.669 \\
\hline Within Groups & 60.740 & 147 & 0.413 & & \\
\hline Total & 61.073 & 149 & & & \\
\hline \multicolumn{6}{|c|}{ Component Three: Preparing Budget and Profit Planning } \\
\hline & Sum of Squares & $\mathrm{df}$ & Mean Square & $\mathrm{F}$ & Sig. \\
\hline Between Groups & 1.613 & 2 & 0.807 & 1.657 & 0.194 \\
\hline Within Groups & 71.560 & 147 & 0.487 & & \\
\hline Total & 73.173 & 149 & & & \\
\hline \multicolumn{6}{|c|}{ Component Four: Valuation of Bond and Share } \\
\hline & Sum of Squares & $\mathrm{df}$ & Mean Square & $\mathrm{F}$ & Sig. \\
\hline Between Groups & 0.840 & 2 & 0.420 & 0.698 & 0.499 \\
\hline Within Groups & 88.500 & 147 & 0.602 & & \\
\hline Total & 89.340 & 149 & & & \\
\hline \multicolumn{6}{|c|}{ Component Five: Financial Statement Analysis } \\
\hline & Sum of Squares & $\mathrm{df}$ & Mean Square & $\mathrm{F}$ & Sig. \\
\hline Between Groups & 1.773 & 2 & 0.887 & 1.491 & 0.228 \\
\hline Within Groups & 87.400 & 147 & 0.595 & & \\
\hline Total & 89.173 & 149 & & & \\
\hline
\end{tabular}

Source: Analysis of Opinion Survey Statement

Considering the significant levels of the different components of financing decisions it has been found that the null hypothesis is accepted in all cases which means that there is no significant variation of perceptions among the respondents regarding the use of accounting information in making process about the different parts of financing decision.

\section{Analysis the Results of Descriptive Statistics}

Table 7: Table showing the results of descriptive statistics about the perceptions of the respondents about the use of accounting information in making financing decisions

\begin{tabular}{|l|l|l|l|}
\hline \multicolumn{1}{|c|}{ Items } & Mean & SD & Variance \\
\hline $\begin{array}{l}\text { Accounting information is used in } \\
\text { selecting the best source of } \\
\text { financing }\end{array}$ & 4.6133 & 0.6323 & 0.400 \\
\hline $\begin{array}{l}\text { Accounting information is used in } \\
\text { assessing cash flows }\end{array}$ & 4.5533 & 0.6402 & 0.410 \\
\hline $\begin{array}{l}\text { Accounting information is used in } \\
\text { preparing budget and profit } \\
\text { planning }\end{array}$ & 4.4533 & 0.7008 & 0.491 \\
\hline $\begin{array}{l}\text { Accounting information is used in } \\
\text { valuation of bond and share }\end{array}$ & 4.3800 & 0.7743 & 0.600 \\
\hline $\begin{array}{l}\text { Accounting information is used in } \\
\text { financial statement analysis }\end{array}$ & 4.4533 & 0.7736 & 0.598 \\
\hline
\end{tabular}

Source: Analysis of Opinion Survey Statement

The results of descriptive statistics notice that the mean values of different components of financing decision are greater than 3.00 but the values of standard deviation as well as variance are poor in this regard that supports the perceptions of the respondent about the using of accounting information in making financing decisions are significant.

\section{Analysis the Results of Reliability Test}

This study has conducted Chronbach's Alpha test to know the reliability of respondents' opinions regarding the use of accounting information in financing decision.

Table 9: Table showing the results of Cronbach Alpha test

\begin{tabular}{|c|c|c|c|c|}
\hline Items & Mean & Variance & Std. Dev. & Alpha Value \\
\hline 05 & 22.4533 & 11.2830 & 3.3590 & 0.9732 \\
\hline
\end{tabular}

Source: Analysis of Opinion Survey Statement

The results of Cronbach Alpha test show that the value of Alpha is 0.9732 that confirms this value is higher than 0.7 which means that the perceptions of the respondent about using accounting information in performing decision making process about the different components of financing decision are reliable.

\section{Conclusion AND ReCOMmendations}

Financing decision is crucial for a company to collect and allocate fund as per the requirement and it basically consists of two major sides of funding sources like internal as well as external sources. Accounting information is the essential element of decision making process which helps interested stakeholders in making decisions about the different components of financing and the attempt of this research is to know the perceptions of the respondents about the using of accounting information in making financing decision. To achieve the objectives of this study has collected opinions from the respondents using 
structured questionnaire and the results of the frequency and percentage of respondents' responses reveal that the majority of the respondents greatly agreed that accounting information has been used in making decision about the different parts of financing decision and also reveal that there is no significant variation among the perceptions of the different respondents in this regard as per the results of hypothesis testing. The study noted that the interested users are always concerned to receive the meaningful accounting information through analyzing the different financial statements because these statements are the most useful platform to make decision. The banking industry should pay attention so that their provided information possess qualitative characteristic so that the provided accounting information can be used by the interested users. This process helps ensure the proper scenario about the operating performance as well as the effective use of the disclosed accounting information to conduct smart decision making process about the different components of financing decision.

\section{REFERENCES}

Ankrah, E. et. al. (2015). The Relevance of Accounting Information in the Management of Small Scale Business in the Yilo Krobo District in Ghana. European Journal of Business and Management, Vol. 7, No. 8.

Begum, R. et. al. (2019). The Effects of Financing Decisions on the Profitability of Commercial Banks: The Case of Bangladesh. Journal of Business Studies, Faculty of Business Studies, Rajshahi University, Vol. 12, No. 1, January-June.

Bukunmi, A. a. et. al. (2018). Assessment of the Effectiveness of Accounting Information as a tool for Management Decision in Manufacturing Companies in Osun State, Nigeria. J Fin Mark, Volume 2, Issue 3.

Das, S. and Das, S. (2008). Accounting Information System of the Financial Institutions in Bangladesh: An Evaluation. https://www.researchgate.net/publication/228271373

Dey, M. M. (2000). A Comparative Study on Readability of the Financial Statements of MNCs and OLCs in Bangladesh. Journal of Institute of Bangladesh Studies, University of Rajshahi, Vol. XXIII.

Gibson, B. (1992). Financial Information for Decision Making: An Alternative Small Firm Perspective. The Journal of Entrepreneurial Fiancé, Volume 1, Issue 3, Spring, December.

Islam, M. M. and Haque, R. (2015). Disclosure of Corporate Governance Compliance of State Owned Commercial Banks in Bangladesh and Stakeholders' Expectation. Research Journal of Finance and Accounting, Vol. 6, No. 20.

Kariyawasam, H. (2016). Relationship between Accounting Information and Human Resource
Management Related Strategic Decision Making in Sri Lankan Manufacturing Companies. IOSR Journal of Business and Management (IOSR-JBM), Volume 18, Issue 12, Ver. 1(December).

Khan, M. Y. and Jain, P. K. (2017). Financial Management (Text, Problems and Cases). McGraw Hill Education (India) Private Limited, New Delhi.

Loqman, M. (1986). Accounting System as an Aid to Management Decisions: An Analysis of the Opinions of Management in Nationalized Industries of Bangladesh. Chittagong University Studies (Commerce), Vol. 2.

Marston, C. and Robson, P. (1997). Financial Reporting in India: Changes in Disclosure over the Period 1982 to 1990. Asia-Pacific Journal of Accounting, June.

Mengistu, M. M. (2015). Evaluation of Financial Performance of the Banking Sectors in Ethiopia: The Case of Zemen Bank. European Journal of Business and Management, Vol. 7, No. 25.

Neogy, T. K. (2012). Factors Affecting the Efficiency of Accounting Information Systems: An Empirical Study. Asian Accounting and Auditing Advancement, Volume 2, No. 2.

Neogy, T. K. (2014). Evaluation of Efficiency of Accounting Information Systems: A Study on Mobile Telecommunication Companies in Bangladesh. Global Disclosure of Economics and Business, Volume 3, No. 1.

Neogy, T. K. (2014). Qualitative Characteristics of Accounting Information: A Study on Mobile Telecommunication Companies in Bangladesh. ASA University Review, Centre for Socio-Economic Research, Vol. 8, No. 1, January-June.

Neogy, T. K. and Ahmed, A. A. A. (2015). The Extent of Disclosure of Different Components of Disclosure Index: A Study on Commercial Banks in Bangladesh. Global Disclosure of Economics and Business, Volume 4, No 2.

Neogy, T. K. et al. (2014). The Voluntary Items of Disclosure and Its Affecting Factors: A Study on Private Commercial Banks in Bangladesh. The Islamic University Studies (Part-C), Journal of Faculty of Business Administration (JFBA), Islamic University, Kushtia, Volume 10, No. 2, June.

Nnenna, O. M. (2012). The Use Accounting Information as an Aid to Management in Decision Making. British Journal of Science, Vol. 5(1), May.

Nwaigburu, K. O. and Mark, B. U. (2014). The Use of Accounting Information is Decision Making for Sustainable Development in Nigeria: A Study of Selected Tertiary Institutions in Imo State. International Journal of Scientific Research in Education, Vol. 7(2), June. 
Ofori, C. F. and Lu, L. (2016). The Impacts of Accounting Information on Managers. International Journal of Novel Research in Marketing Management and Economics, Vol. 3, Issue 3, September - December.

Olaifa, O. I. (2018). The Effects of Financial Decisions on the Performance of Commercial Banks in Nigeria. European Journal of Business and Management, Vol. 10, No. 8.

Pandey, I. M. (2017). Financial Management. Vikas Publishing House Pvt. Ltd.

Sanyaolu, O. A. et al. (2017). International Financial Reporting Standards Adoption and Earnings of Quoted Banks in Nigeria. International Journal of Economics and Financial Issues, 7(1).

Sirisha, S. and Malyadri, P. (2018). A Study on the Financial Performance of Scheduled Commercial Banks. International Journal of Business and Management Invention (IJBMI), Volume 7, Issue 2, February.
Socea, A. D. (2012). Managerial Decision-Making and Financial Accounting Information. Procedia-Social and Behavioral Science 58.

Srivastava, P. and Lognathan, M. (2016). Impact of Accounting Information for Management Decision Making. International Journal of Applied Research, 2(5).

Tunji, S. T. (2012). Accounting Information as an Aid to Management Decision Making. International Journal of Management and Social Sciences Research (IJMSSR), Volume 1, No. 3, December.

Ullah, M. H. et. al. (2014). Role of Accounting Information in Strategic Decision Making in Manufacturing Industries in Bangladesh. Global Journal of Management and Business Research: D Accounting and Auditing, Volume 14, Issue 1, Version 1.0.

Zager, K. and Zager, L. (2006). The Role of Financial Information in Decision Making Process. Innovative Marketing, Volume 2, Issue 3.

\section{How to cite this article}

Saha, S., Sil, S. C., \& Sayaduzzaman, M. (2021). The Use of Accounting Information in Financing Decision: The Context of Bangladeshi Private Commercial Banks. Asian Business Review, 11(1), 15-20. https://doi.org/10.18034/abr.v11i1.514 